\title{
The Roots of the Organized Criminal Underworld in Campania
}

\author{
Pasquale Peluso

\begin{abstract}
Department of Public Politics and Administration Sciences, “Guglielmo Marconi” University, Rome, 00144, Italy
\end{abstract} \\ *Corresponding Author: p.peluso@unimarconi.it
}

Copyright @ 2013 Horizon Research Publishing All rights reserved.

\begin{abstract}
The Camorra is a closed sect that acts in the shadows and does not collect and preserve documents that can later be studied by scholars or researchers. It is hard to rebuild the history of the Camorra: the picture is fragmented, a mix of half-truths and legends. The aim of this article is to make a diachronic excursus in order to find out the origins of the Neapolitan Camorra, that has had a longer history than any of the other mafias, and to explain how this secret organization has changed its main features from 1800 to the present and from the Bella Società Riformata to Nuova Camorra Organizzata. Finally the modern clans that fight to keep the possession of their territory and operate like financial holdings in order to improve their business through legal and illegal affairs.
\end{abstract}

Keywords Crime, Organized Crime, Crime Association, Camorra, Illegal Economy.

\section{Introduction}

From a criminological point of view, it is interesting to understand the influence that such a crime organization, the Camorra, has had on its members and territories where it carries out its legal and illegal activities. It is relevant to examine the evolution that the Camorra has had over the years and its changes inside the social context.

From a mechanism of social control, nowadays the clans also have economical interests. This change is influenced and connected to the loss of urban connotation of the Camorra as it has now a regional, national and international connotation, abandoning the Camorra of alleys without losing its authority on their followers.

In fact each clan is able to convey particular values to society and young people: these values attract them to the criminological pact, especially if social, institutional and cultural reference points are absent.

The rules, facts, business, rituals, and strict discipline emphasize criminological aspects, to point out the influence that Camorra has had on the society and its affiliates.

The aim of this research is to analyze how the Camorra was born and how it has changed and developed over the centuries, transforming from a rural Camorra to a metropolitan one and finally to an entrepreneurial modern Camorra that uses different methods in order to manage its affairs threatening the nation.

\section{Methodology}

The research has suggested a detailed picture of the crime phenomenon and connected the study of a large number of documents contrasting the Camorra and the careful assessment of sources about the topic.

In a diachronic prospective, the enquiry points out the most relevant features of the Camorra, especially the crime realities on the Campania territory, without neglecting those elements concerning collective behavior from the study of clans, the characteristics of crime business and nets that make a thorough analysis of the crime phenomenon of the Camorra possible.

\section{Results}

In literature, it is hard to describe the "Camorrist" phenomenon and its characteristics due to its dynamics, the high number of clans, and its open organizational nature. Like all secret societies, the Camorra is a closed sect that acts in the shadows and does not accumulate and store documents that can later be studied by historians.

The history of Camorra can only be revealed by confessions of former members. Such sources produce a fragmented picture with a mix of facts and half-truths, as well as fantasy and legendary accounts. Yet, the Neapolitan Camorra has had a longer history than any of the other mafias. Many theses or theories are formulated about its origins.

Some hypothesize that the Neapolitan Camorra has Spanish origins. It is possible that the name "Camorra" began by the playhouses, which was the term associated with the Spanish boys that worked for the aristocratic boss of the time. These individuals abused their power and lived in and 
used name their "Compagnoni"[1] or "Compagni", which are nicknames used today by "Camorristi", the men of Camorra. Another version of the emergence of the Camorra was given to a captain of the Carabinieri (similar to policemen). For example, on March 11, 1911, Carlo Fabbroni was given this name by his informers. Fabbroni fixed the date of the founding of the secret society at 1654 when the Spanish adventurer Raimondo Gamur was arrested in Naples and confined in Castel Capuano's jail. Gamur, according to this version, so inspired the Neapolitans, that upon their release, they went about putting into practice the "Spanish theory". He made the acquaintance of five Neapolitan cellmates, and they enrolled all malefactors in the criminal conspiracy. This organization had its own code of conduct, hierarchy of command and bosses. The word "Camorra" was said to be the Neapolitan dialect (idioma) rendering of the surname "Gamur"[2].

Many Italian criminologists are convinced that the Camorra arose in the prisons, as determined by Antoine Perrenot de Granvelle in 1573. Mirabella[3], instead, said that the Camorra's origin is in 1800 s, based on the slang and customs of the Camorristi, carried out among inmates of the Favignana's jail, an island off the west coast of Sicily. Here, a type of questionnaire was discovered, that was used to judge recent arrivals. If a new inmate claimed to be a Camorrista, he would be subjected to a series of questions to determine whether he was an affiliate, a common criminal or, worse yet, an undercover policeman.

The latter part of the questionnaire contained the queries about origins. The new arrivals could correctly answer by saying, "Three gentlemen, one Spanish, one Neapolitan, the other Sicilian were playing cards. At the end of the game, the Spanish man took $20 \%$ of the winnings for himself. He then declares, 'I take this $20 \%$ cut as my right and by law of the Camorra'. The three men came to an agreement by founding the Society of the Camorristi and recruiting others as affiliates, with the objective to take a percentage from gambling"[4].

However, the reference to the Sicilian gentleman constituted an explicit reference to the Mafia, a sister organization". The game has become the legend that tells that the Camorra begun by Spanish word "Camorra", which means altercation, disputation and brawl[5].

One legend that derived from Camorra is the Arabic and Spanish word "kamur", which means the dice's game. Further, another legend puts the origin of Camorra in the Mediterranean word "morra", which means brawl. Not to add to the confusion, but this is also a Neapolitan game. For this legend, the Camorrista is the morra's boss and he directs the game, taking money. Apart from the development of the hazard game, the Spanish domination influenced the Neapolitan society through the urban aspect of the city, the use of obscene language, blasphemy, superstition practices, dirty, begging and homosexuality. The Spanish, in fact, revealed to Neapolitans the organization of our secret society named "Guarduna's Confraternity" with the object being to organize murders and other activities of this type[7]. This secret society was founded in Siviglia in 1417 and was working in Spanish until 1822, when its boss, Francisco Cortina, was arrested. This society had the contacts with guards, kings, inquisitor bishops, and magistrates. The members of this society applied the term "sfregio" [8] to third persons, and they made it permanent by rubbing on "sego"[9] dissolved in vinegar.

The society's boss' was named "Hermano mayor" and was a very powerful man, united also with the politicians[10], and gave orders to "capatazes" (provincial boss). The "Guarduna's Confraterniy" had a constitution named "el camilludo"[11] and as with almost religious ceremonials she committed crimes. The "el camilludo" used by Bella Società Riformata to draft its constitution named "Frieno", but the "Frieno" in was at first only an oral constitution. Because there are different interpretations of the rules of the "Frieno", in 1842 it was written in a solemn ceremony.

Again, today, the word Camorra means underworld behaviors and unfair and dishonest actions. Often, the Society made good actions so as to give back the stolen goods and protect the weak. For this reason, the Camorra were antagonists of the "State" and it was made famous among the people because it was the order's tutor and the justice distributors, filling the lacks of the "State" and increasing its power.

In the 1800's, the Borboni kings consolidated the Camorra, using the aristocratic manners[12]. It was transformed into a secret society named "Bella Società Riformata". In fact, the "Bella Società Riformata" was born in the 1820 when the man from the Naples's twelve quarters convened in the "Santa Caterina in Formiello" Church and during a solemn ceremony gave a new character to the Society. The chief had to be a native of the "Porta Capuana" and a quarter Neapolitan[13], where many of the nefarious lived. The central idea that gave life to the "Bella Società Riformata" was borrowed from the usages of the aristocracy, the nobility.

The history of that period, from 1820 to Italian Unification in 1860 , was a series of political struggles, often with bloodshed, between the absolutism of the aristocracy and the middle classes, which had their own societies to protect and promote class's interests.

One example of another secret society was the "Carboneria," an Italian secret society born in South Italy in 1807. The "Bella Società Riformata" hierarchical structure was borrowed from the "Carboneria" organization. At the top of the "Bella Società Riformata", was the "Capintesta", who was democratically elected. He over saw twelve "Capintriti", the head quarters, that tell him the city's news and gave him the money extorted from the designed victims. The "Capintriti" received the news about anything in the quarter by the "Camorrista di giornata" a daily camorrista similar to a picket's officer. Another category in the Camorra's structure is named "Contaiuolo". The "Contaiuolo" is a cashier that proceeded to distribute the 
extorted money between the "Capintesta" and "Capintriti", from which they kept part of the money to use to pay off corrupt policeman. The other part of the money was distributed among the other members of the "Bella Società Riformata" named the "Capiparanza", who were the group leaders. They had particular specializations, and "Camorristi di giornata" who were daily racketeers.

The neophytes consented to judgment while blindfolded, with one hand on a dagger and the other on a crucifix. One member of the "Bella Società Riformata" recognized another by special symbols, various hand contacts and code words, which changed every six months. Punishment, including death, could befall those who were deemed liars or traitors. While the others sects had socio-political programs (the "Maisons" were generally philanthropic, the "Carboneria" securely patriotic), the "Bella Società Riformata" was apolitical and its agenda obviously unique. The "Bella Società Riformata" incorporated good and bad things from nobility, especially its arrogant egoism, its sense of privilege, and its corrupting nature, as best illustrated by the selection of a meeting place.

The "Carboneria" choose the splendour of the "Santo Spirito" Church, while the "Bella Società Riformata" convened at "Santa Caterina in Formiello" Church located in a neighborhood of common folk, brothels and where the public was firmly under the control of unsavoury elements. As did the "Carboneria", the organizational structure of the "Bella Società Riformata" had two sections: the Società Maggiore and the Società Minore. Its ritual of initiation was a sort of grotesque parody of the Carboneria. The Società Minore ceremony, reserved for entering youth, was quite bloody. The "Bella Società Riformata" members, each wielding a dagger, circled the aspirant. A coin was placed on the floor. At a signal, the members stabbed at the coin while the initiate attempted to retrieve it. Hands were slashed, but the test for courage and tenacity was completed. The new members entered the exclusive Society as "Giovanotti onorati", honored youths. Knowing of the initiation rite, when the police arrested a suspect the right hand would be checked for evidence of savage scaring to determine whether he could be charged as a Camorrista.

In this Società Minore, there were also the "Picciotti" and the "Picciotti di sgarro". After the "Giovanotto onorato" served his apprenticeship, he was eligible to be promoted to the inner ranks of "Società Maggiore". The formal ceremony took place in a darkened room. By the light of a single candle, the candidate sat at a table on which lay a dagger, a loaded pistol and a glass of poisoned wine. A barber/physician drew blood from his hand with the dagger. He then extended the hand to his comrades and swore to obey the orders of the capo and not reveal the secrets of the "Bella Società Riformata". Pointing the pistol to his temple while lifting the wine glass to his lips, he swore to kill himself if he received the order to do so. At this point the capo took the pistol, fired it into the air and smashed the glass to the floor. The youth knelt. The capo, putting his hand on the youth's head, pronounced the final words, "You are now a man!" It was understood that to speak the name of the "Bella Società Riformata" chief at any time meant death.

The Neapolitan social contest in the first half of the 1800's was infamous for its utter disorder, images of extreme poverty, merry making and filth. Street vendors hawked a variety of merchandise. Street urchins in rags roamed about, specializing in the theft of handkerchiefs[14]. All Neapolitan people competed in an atmosphere of the unwashed.

It was among this multitude that the "Bella Società Riformata" found its opportunities. The streets of Naples contained men who invited gullible passers-by from the provinces to try their hand at games of chance. By tradition, these open-air gambling operations were "protected" by the Camorristi. They took their twenty-percent off the top. The gamblers had cheerful demeanors; they accepted without complaint paying the price to remain in business and not be hassled by anyone.

On a regular schedule, the extortion collectors would stroll from one table to another taking the tax with ceremonious courtesy. The "Bella Società Riformata" extortion racket was widespread, touching a score of jobs: baggage handlers at the port, hotel clerks, carriage drivers, street vendors, even common thieves, whose pickings were usually modest. Among activities of the "Bella Società Riformata", there was the exacting of a tribute from prisoners on "Our Lady oil tax" [15].

The list of the Camorra's activities was very long. In fact, members of the "Bella Società Riformata" functioned as arbiters and middlemen. They kept the peace. They settled disputes between sellers and buyers, renters and owners, creditors and debtors, workers and employers, all for a consideration. Most of all, they intervened in questions of honor, which otherwise would come to a bad end, given the importance of questions of honor and the "lose of face" sentiment among Neapolitans. A seduction was a delicate subject to be treated seriously. In order to "save family face", and prevent the aggrieved father (or oldest brother) from acting in haste, the middleman had to tread a diplomatic path between the two parties. Immediate nuptials were one solution.

In these and other disputes, the formal judicial system either did not suffice or was ignored. Foreign rulers came and went, but the more personal and traditional relationships to family, neighborhood and class were what counted. There was little trust in the state mechanism; bureaucrats were seen as corrupt and not serving the best interests of the populace. Camorrista justice at the local level among likeminded persons was considered a better, if only, option. Those who hesitated to settle or were quarrelsome, or were so rash as to resort to a magistrate for relief, risked confronting the stiletto, the weapon of choice to settle matters. The "Bella Società Riformata" was a government within a government, and in some neighborhoods, it trumped the legitimate government to the extent that the authorities would not enter neighborhoods where the Camorra held sway.

The "Bella Società Riformata" had its own courts called 
Mamme[16], which meted out internal justice. Gran Mamma was the superior tribune, with the characteristics of a court of appeals or a court of assize (civil or criminal court). There were ten appeals courts that had regional jurisdiction.

The Camorristi could resolve individual issues as they saw fit. However, when the issue had implications for the entire organization, as in a disgraceful action accompanied by an official accusation, the case had to be reviewed by the "Bella Società Riformata" district magistrate. The Supreme Court[17] was composed of the "Mammasantissima" as the very holy mother, who sat as President, a Court Clerk, four or five members acting as Judges and Defense Lawyers, and a few members (two) of the Società Minore as guards. In the court, there were the "Contaiuolo" as State Prosecutor and a Court Clerk. If the sentence was death, the executioners were chosen from the "Giovanotti onorati" by drawing lots. Lesser punishments included a reduction or suspension of the share of money, public humiliation in the form of a slap, scolding or beating, or a razor slash on the cheek. Even the smearing of human feces on the face was a possibility. In capital offenses, the condemned would suffer a fatal dagger in the chest, or in the worst case, in the groin.

The controversies, instead, were born between Camorristi, and could personally be regulated through the rituals of the "zumpate" and the "dichiarimenti"[18]. The "Frieno", (as previously mentioned), was the Camorra statute and it was inspirited to "Guardugna"[19] of Spain. It was never written out, but instead it was known only as an oral law. In 1842, the secretary[20] of "Bella Società Riformata" wrote a new and modern law entitled, "Frieno", composed of 26 articles[21]. A thanks that the "Bella Società Riformata" achieved the democracy at one's inside. The new "Frieno" was promulgated in "Santa Caterina in Formiello" Church in September 12th, 1842.

At first, the Camorra took its revenue through the collection of the "pizzo"[22] paid by numerous "biscazzieri"[23], which crowded the roads of Naples. Subsequently, the "pizzo" was imposed on all storekeepers. Other income sources of Camorra were: the "barattolo", that was a extorting $20 \%$ of the biscazzieri's incomes, the "sbruffo", that was a particular "pizzo" paid to all storekeepers; the clandestine lottery named "gioco piccolo"; they extort the brothels and the prostitute's protector with a variable amount[24]. Through the "Capintriti", the Camorra was in charge of its activity and made those "legal" activities, because it provided a few services to people [25].

The first bond between Camorra and politics was in 1860, when the police prefect, Liborio Romano, in order to keep law and order at the patriot Garibaldi arrival, entrusted to Camorra the city guard's organization against the popular rebellions[26]. In this manner, the Camorra could follow its skills under the aegis of the State[27], until the early of 1900s, when the State reacted to Camorra. At that time, the Camorrista began the "peace's judge". At the time of Francesco I[28] King, under the regency of Ferdinando II[29], the Camorrra ran the order in the jails[30], where there were many murders because of the article 15 of the Bella Società Riformata's "Frieno"[31]. Further, the Camorra had contacts with a temporary society inside prisons. In fact, four Camorristi "under lock and key were necessary to elect the temporary "capintrito" that returned a common Camorrista when he left the prison.

In prison, the "Capintrito" ran the arms. He could impose penalties, define abuse of power of any type, and he required to be served and revered by other prisoners[32]. Also in the prison, the "Contaiuolo" ran the accounting and the money that derived from "Our Lady oil's" tax. This tax, as previously mentioned, was applied to prisoners that did not belong to "Bella Società Riformata". The new prisoners reinforced the sect and the foundations of the sect. The Camorra prison was also strong in islands, where there were the penal baths and compulsory houses. At the end of 1800's, the "Bella Società Riformata" was modernized for the contacts with politicians, and it joined forces with cunning and impudent middle class men. These men were skilled in the trades, contracts, political meetings, public administrations, circles and the press, due to their education.

The new Camorra was based on the electorate. In exchange for a vote, it gave protection, assistance and recommendations. The government was strongly repressive, but was defeated by influential men that the Camorra carried to power them. In this manner, the sect had lost the form of a criminal, proletarian and plebeian association[33], because also thieves joined its organization. The thieves, who stole and robbed, alternated between patriotic and generous behaviors. The new "Bella Società Riformata" accepted all types of people in order to increase the electorate. For this reason, in the early 1900's, the rise of new "Capintesta" created a sort of "diarchia" with a real "Capintesta" similar to "the first minister", and the honorary "Capintesta"[34]. The base of Camorra was changed too. A "Camorrista scelto" was placed near to each "Capintrito". The Gran Mamma Court continued to meet in the "Fontanelle's" Caves. The Camorra profit derived from its taking part at political and administrative summit meetings, in which the Camorra imposed its affiliates as candidates to be elected, discouraging the adversaries by threatening them. Further sources of profits were money from extortions and clandestine lottery.

During that time, the crimes increased and the "Bella Società Riformata" did not run. It was tolerated by the nobility whom they opposed. In the last decade of the 1800's, and the first of 1900's, the years were difficult. Although the "Frieno" was modified[35] and the "Capintesta" were very able in their work, in 1912 the "Bella Società Riformata" was untied, after the Cuocolo murder and the spouse's killing. The Cuocolo were affiliated with the Camorra and their murder was given to a "Capintesta" of this time, Enrico Alfano, and his closest collaborator, after manoeuvred inquires[36].

Alfano and his collaborators were sentenced in Viterbo's Court and the esoteric Camorra was destroyed. On the night 
of May 25th, 1915, inside the "Fontanelle" Cave in the "Sanità" quarter, the "capintesta" Gaetano Del Giudice declared the end of the "Bella Società Riformata". At that time, the criminal activities was executed by many people, but they were of a delinquent nature "more dangerous than common crime, but less dangerous than mafia"[37]. The Neapolitan's Camorra was revived when the Italian gangsters in the U.S.A. constructed a criminal society with local criminal groups. An example of a society that was created by American gangsters was through a Sicilian named Lucky Luciano[38]. He, along with Neapolitan Vito Genovese[39] worked in order for American Allied to disembark in Italy, as requested by the American authorities. In Sicily, the Americans favored the appointment of a Mayor to the old gangsters, while in Naples the Americans favored the contraband and clandestine (black) market.

In this manner, independent criminals used their power to abuse the common people. In this picture, the "guappi", the "price's presidents", and the "livestock agent" stood out. They were characterized by traditional Camorra's, folk's and urban gangster's aspects. Since that moment, the "zumpata" and "dichiaramenti" rituals were left, but an increase in the number of gun duels occurred in the crowded streets. In Naples, after the Second World War, many "guappi" were in competition for their share of the extorted money in the markets. For example, the "blonde market"[40] was controlled by the Giuliano Brothers, the Spavone Brothers, and the Mormone Brothers, while the fruit and vegetable market was controlled by Alfredo Maisto[41], Raffaele Baiano, Antonio Esposito and Pasquale Simonetti. Often, among these people, there were mortal duels because everyone wanted to overcome somebody.

In fact, when he was 18 years old, Antonio Spavone killed Giovanni Mormone, who was called "O mpicciouso" (hindrace), because Mormone had killed his brother Carmine. Antonio Spavone[42], called "'O malommo" (bad man) killed his cellmate in Procida, but he rescued his fellow inmates and the Prison Director's daughter in Firenze during the flood of 1966. For this reason, the Italian Republic President, Giuseppe Saragat, granted to him a pardon[43].

Another important "guappo" was Pasquale Simonetti, called "Pasqualone "e Nola" (the big Pasquale from Nola a Campania's city). He became the "price's president" of the fruit and vegetables market because, in 1951 at the Agnano Racecourse, located in a quarter of Naples, he slapped Lucky Luciano. He had many duels with Antonio Esposito[44], called "Totonno "e Pomigliano" (Tony from Pomigliano d'Arco other Campania's city). He wanted to become the "price's president" as well. When Pasquale Simonetti was killed by hired killer, his pregnant widow Pupetta Maresca, shot and killed Antonio Esposito, believing him to be instigator of the Simonetti's death, near the Naples's rail station[45].

At that time, Campania began the first relationship with the Marsiglia's criminal groups and with the Sicilian Mafia that created new organized systems and crime's exploitation[46]. A "triumvirate"[47] was created, which organized a National summit and subjugated the Neapolitan "guappi". The Sicilian mafia prevailed on Marsiglia's organized crime and Lucky Luciano and his "unwanted" group in Naples, with the help of corrupted chemical farms whom supplied him with drugs, introduced the New Camorra International trades together with to "Cosa Nostra".

In 1959, when the free port of Tangeri (Tunisy) was closed, the national and international contraband's headquarters was moved in Campania. This was a location where many dangerous and important men of "Cosa Nostra" stayed against their will. In this manner, Camorra acquired Mafia manners[48] that together with the abandoning of Naples by Marseilles gangsters, and the explosion of the drug's market, changed the criminal universe in Campania. Nevertheless, the Camorra abandoned the "economia del vicolo"[49] (alley economy), but maintained the city control and became an entrepreneurial Camorra. Halfway through the 1970's, the Camorra were transformed, thanks to Raffaele Cutolo. He created a much detailed and powerful net of criminal organizations in Italy, by applying the tactic of "scientific extortion" [50].

While the "Bella Società Riformata" used nicknames created on the basis of attractiveness of behavioral characteristics, the nickname of Cutolo was "'O professore" (the professor) for his knowledge, especially on "Bella Società Riformata"[51]. Cutolo recreated the old organization and he named the New Camorra the "Nuova Camorra Organizzata" or "N.C.O." (New Organized Camorra). Cutolo, named himself "State of Poggioreale's[52] Leader" or "N.C.O. Prince" or "The Great"[53]. He was arrested in 1963, when he was 20 years old, for Mario Viscido's murder. Viscido was killed because he offended Cutolo's sister Rosetta. Cutolo was sentenced to life imprisonment, but the sentence was reduced to 24 years by the Court of Appeals. He left prison in 1970 once his sentence was complete, and after his appeals to the Court of Cassazione.

In prison, Cutolo invested his extortion money to improve the life of prisoners. For this reason, Cutolo became very important among "Giovanotti onorati" (distinguished youths)[54]. These youths became members of N.C.O. Cutolo and frightened the other prisoners. He was respected because he used to walk with a book in his hands, or be absorbed in reading in his cell. He was more concerned with reading than his sentence for murder[55]. In prison, Cutolo helped prisoners that could not read and write, which is a necessary asset in order to assist prisoners with approaching others and introducing people to family, lawyers and friends. In order to increase his power, Cutolo challenged Antonio Spavone, named "'O malommo"[56] (the bad man) to a duel. The duel did not happen, but the gesture itself increased the fame of Cutolo.

As to "Bella Società Riformata", the relationships of N.C.O. extended its trades from cigarettes and contraband to drugs, building sites and trade activities[57]. Cutolo believed that the Camorra was born in prison, via recruiting the young men that stayed at the base of organization, and forming 
alliances with other criminal and political-institutional men. To achieve this goal, Cutolo eliminated the independent crime and gave a hierarchy to the N.C.O., where the only leader was "'O Professore".

In 1970, Cutolo founded the N.C.O., enforcing the methods and customs of old Camorra and Spanish sect of "Guarduna". According to Cutolo, the N.C.O. could use a statute, a hierarchical structure, an oath that could influence and excite the affiliated to risk to their own lives[58]. For this, Cutolo used the initiation rites of the 'Ndrangheta[59] in prison. After the test on the blood's oath, the affiliates were separated into: "Capizona" as area's boss, "Sgarristi", "Santisti" and "Fuochisti"[60] that set the strategic leadership, and "Picciotti", whom set the base.

The "Capozona" could collect the extorted money, paid by subjects. Every month the "Capozona" gave to Rosetta[61], the Cutolo's sister, 500.000 of old Lire (now worth $260 €$ or 350 \$ c.ca). The ritual of affiliation or of "fidelizzazione" exalted the group's spirit, especially in the young who could oppose the expansion of "Cosa Nostra". According to Cutolo, "Cosa Nostra" wished to colonize the Camorra.

The hierarchical structure aided to organize the racket of extortion, selecting the victims and transforming individual objectives in to common objectives. In this manner, there was an effective "predatory phase"[62], with a large accumulation of money and consequent investments.

At that time, Cutolo instituted an alliance in an extra region expanding the Camorra in all of Italy and recruiting the sub city young conscription. From inside prison, Cutolo realized the strongest and bloodthristiest crime organization with strong roots in the local territory and political institutional connections[63]. The N.C.O. had the right to be a unique speaker of "Cosa Nostra" for the drug trade[64]. In fact, Naples became an important junction in Italy and Europe for drug traffic, because it had an intertwined network[65]. But the agreement didn't establish a total alliance between N.C.O. and "Cosa Nostra" as they preserved their identities, peculiarities, and autonomy in own territories. This kind of trade monopoly induced Cutolo, neglecting the limits of the agreement, to require the "pizzo" even to smugglers of the mafia's clans[66]. As a result Cutolo invaded the "trading" areas of independent clans. Cutolo was born into the "Nuova Famiglia" (the New Family), and wished to become speaker to "Cosa Nostra" about the drug trade [67]. Between 1979 and 1981, the "Nuova Famiglia" was composed of the independent gangster families of Zaza, Giuliano, Vollaro, Nuvoletta, Ammaturo and Alfieri. The alliance of those families could serve the temporary and unique purpose of annihilating Cutolo.

The "Nuova Famiglia" foundation of the federation was dated back to December 8th, 1978 on the promotion of Giuliano's and Zaza's Family[68]. During the meeting, it was established that the "Nuova Famiglia" would never became a unitary organization as the N.C.O. of Cutolo, and that the families were to remain separated with delimitated spheres and autonomous prerogatives.

The hierarchical ranks were named "rialzi" (rises) with affiliations and oath rites similar to N.C.O. The affiliation was named "copiata" (copied). Even the N.F. had its own severe and bloody court, as the nineteenth century Camorra[69]. From 1980-1983, the conflict between "Nuova Famiglia" and "Nuova Camorra Organizzata" led to more lives lost than ever before. The fame of Cutolo, was well known to "Brigate Rosse"[70] (Red Brigades) or B.R., the terrorist group, subversive, of extreme left wing of Italian Parliament that in those times had many of their own men in prison. When he was in Ascoli Piceno's prison, Cutolo established friendships with members of the "Brigate Rosse", and they established an agreement[71]. This agreement determined the reciprocal favors to be given and received. In fact, Cutolo intervened in Counselor Ciro Cirillo's kidnapping[72].

To release the councillor, the managers of the Christian Democrat Party, came to an agreement with "Brigate Rosse"[73]. The contacts between politics and terrorists were established by Cutolo, but the mode of those contacts among politicians, secret service, and Camorra representatives, have been kept secret. Perhaps, the same SISDE's officers started the first negotiations with Camorra. In Ascoli Piceno's prison, administrators began monitoring the comings and goings of politicians and policemen that paid homage to Cutolo. He finally convinced the members of "Brigate Rosse" to release the Counselor Cirillo. On July 25th, 1981, after 89 days of imprisonment, he was released.

The war between "Nuova Camorra Organizzata" and "Nuova Famiglia" continued until 1983, leading to hundreds of the deaths. In this year, the "Nuova Camorra Organizzata" was defeated, thanks to the contrast activities of the Police, and the spread of "pentitismo" phenomenon[74] (confessions by criminals) and "defezioni" (defections).

In that year, the "Nuova Famiglia" stopped their activities because its clans resumed their own autonomous and conflict programs. In this period, the clans of "Nuova Famiglia" began alliances with them, as for example, the alliance between Lorenzo Nuvoletta and Antonio Bardellino[75].

In 1992, Carmine Alfieri[76], already a member of "Nuova Famiglia" and an historical leader who was anti-Cutolo, attempted to construct a unitary organization, according to Sicilian plan. He named that new organization "Nuova Mafia Campana" (New Campania Mafia). According to the Anti-Mafia committee, "The Nuova Mafia was more aspiration than realization"[77].

In its historical evolution, the Camorra was distinguished from the other criminal organizations by the following characteristics: it became integrated with the poorest people's layers, it took root in the society and culture in the urban environments, and it had "mercenary" relationships with politics and institutions in order for their illicit business to be tolerated. Today, the Camorra has a solid horizontal structure comprised by numerous clans. These clans were easily set-off, and easily upset, which often caused 
shoot-outs. These shoot-outs determined the end of either. The Camorra boosts the "Neapolitan globalization"[78] through a criminal economy, and joined the business world.

There are many differences between Camorra of the city and Camorra of the province because the first is less joined to politics and does not have political ideologies. It is available to any one that can return its favors. If Camorra supports political causes, it joins a single politician[79]. The connections with politicians are never immediate and explicit. The Camorra exploit the social disorders in order to govern and becomes a social rise's channel for the underprivileged classes that want to obtain easy and fast wealth[80]. The city's Camorra searches political protection, but it cannot control and exploit huge illegal markets, and illegal business, because it does not have the necessary power[81]. The Camorra is everywhere. What is necessary is its protection, because there are benefits to making profits, there is a profitable activity to play, and there is a political relationship to start. All this, because it wants entry in the heart of all "sottomercati" to order to be its own contractor, and to be the sales executives for many people.

For this reason, the Camorra has a particular relationship with the territory. In fact, even if the bosses are hunted by police, they do not go away from the city, because they would lose their authority in the area. This situation permits useful inter-exchange with anybody that is interested.

The clan's boss knows that they are supporting men who are ready to take their place as soon as they slack in their ability to take control of the situation. Because of this, often the young are the clan's boss. The boss is usually presented as a powerful man to all people of the quarter. The people must obey and have reverence for the boss, because the boss has the ability to have the last word on the working or simple subsistence destiny of the quarter's men.

Camorra strategy is to surround each clan's boss with a cordon of family always in defense of the boss, especially when he goes into hiding. This family become squatters of the public housing units built with grants for reconstruction. Thanks to the local and regional government's inertia, and five laws to solve this situation, fortresses have worked as a base for the individual organization. These squatters were discovered by the end of 90 years. In 1997-98, the public housing units of "Taverna del ferro" e "Pazzigno"[82] quarters were cleared. Just as with the feud between Di Lauro clan and the "scissionisti" (divisioners), the function and the size of this phenomenon was analyzed and became well-known. As the State Prosecutor Corona says, "the squatters are the best form to occupy the territory"[83].

In that quarter, often there are the operations that can be referred to as "ethnic cleansing" as a motive. With these operations, the clans put the honest families to flight in order to conquer the territory. Also, the Di Lauro clan had sent away approximately 100 families, threatening those that lived in the "Casecelesti" (sky blue houses) quarter. To do this, the clan killed a man and set fire to 10 houses left by "avversari" (adversaries). In the east Neapolitan zone, there are 7 fortresses, 4 of which are "Pazzigno" and "Taverna del ferro" (hole tavern) in "S. Giovanni a Teduccio" quarter, "Lotto 0" in "Ponticelli" and the "Case Gialle" (yellow houses) in Barra. The other 3 fortresses are the "Parco Verde" (green park) in "Caivano", "Quartiere dei Fiori" (flowers quarter) and "Case celesti" (sky blue houses) in "Secondigliano," and they are in the Northern Neapolitan zone. It is notable that the clans are favored by the architectural shape of those quarters. For example, in "Scampia", the house site is half-underground and closed in by a fence. It continues into a "palizzate" that forms a canyon[84]. This shape inhibits anyone trying to penetrate in order to drive out the criminals. Moreover, the clans added many passive protective measures such as gates, walls, reinforced doors, dissuasive bolts, reinforced sentry boxes, and television cameras, in order to make access by the police and the rival families' representatives impossible.

Among the active protective measures are sentries, who are ready for anything. They watch any corner and any part of the street in order to prevent attempts on the boss's life. In the "Case Gialle" in Barra, there are some forced evictions of public housing units' assignees to permit the entry of the families linked to the clan that controls this territory. Obviously, acting in that manner, the clan makes sure the fidelity and favors to the boss are passed on to the newcomers. In this manner, the clans create the micro-societies similar to feudal society that permit the boss to make them fugitives without leaving their territory[85]. The affiliation of tenants permits the boss to change his hiding place continually without losing the contact with the territory.

The sociologist G. Amendola[86], an expert in urban safety and one of most well known Italian researchers on the "Zero Tolerance" or the "get tough" policy, believes that the "Zero tolerance" model isn't exportable to the Neapolitan context. In reality, Hope Corman and Naci Mocan, economists from Rider University in New Jersey and Colorado University, respectively, who were also consultants during Giuliani's administration, analyzed the famous "get tough" approach. This approach was actually started by Mayor Rudy Giuliani of New York, in order to hit the minority crimes with special severity, by discouraging the criminals to commit more grave offenses. Emphasis has been placed on this approach, demonstrating that it has had an effect on the reduction of other offense types more than the yield increased and unemployment decreased[87].

If the institutions had tackled the squatting of some houses, built in some Neapolitan districts after the earthquake in 1980 , the clans wouldn't have taken possession of this areas, transforming them in the Camorra fortresses. Would stopping this behavior increase the difficulty for the clans to take possession of those making the fortress? Sometimes, the clans are distinguished for the brutality of their crimes[88]. According to the scholar Sales, from a social point of view, the Camorra is considered a way and a price to be paid in order to reach balance and stability, which cannot be achieved in a different way because of the city conditions. [89]. 
In fact, the Camorra governs the social confusion and settles the illegality that overwhelms the limits of the city. In this manner, the sub-privileged classes themselves begin the "introverted rebellions" that occur inside and dissolves the justification for a possible social riot. Like this, the free practices of illegal activities are tolerated and even protected by the authority. For the spreading of productive activities, the wealth outside from the metropolitan context, the Camorra has lost its specific urban traits and so the Camorra has become an international phenomenon, in the last decade[90].

The internationalization of the Camorra has taken advantages by social confusion, institutional hiding and the economic crisis that induce to commit different crimes. It is difficult to make room among the clans in positioned territory. The clans were born, and their roots are especially in the zone of their boss' origin, and therefore, they take a homonym name[91].

The detailed settlement of criminality in the State-district as, like "Forcella" (fork), "Sanità"[92] (health) and in vast geographical zone, like "Scampia" and "Secondigliano", are sources of direct earning of criminal models, criminal techniques and diverting values. This zone is the first socialization agency for the young people and has a principal role in the formation process of young identity[93]. But more often, some studious individuals think that these are the reasons that the origin to affiliation of new recruits, true successors of "muschilli"[94] because they are always in need of cover roles and tasks that can make them feel like part of the organization. In fact, the Camorra try to entrust the younger people with different duties: first they will use them as drug couriers, then make use of them for other illegal activities from robbery to murders. Only the best younger protégés will be admitted into the Camorra society. Camorra uses the young people because in Italy the imputability is excluded for minors under fourteen years old. On the contrary, the judge must determine on a case by case basis, the imputability of minors under eighteen and over fourteen.

Nevertheless, the major difference between Camorra and Mafia is that the Camorra is a set of criminal organizations without a hierarchy and without unitary direction or a common criminal strategy[95]. That is, the Camorra is a set of gangs but without (Mafia) high command, and for this it is "plural" by point of view geographic, social and politics. The fragmentation of camorrist gangs creates the true criminal anarchy and motivates the homicidal violence used in the group's disputes. The superimpositions in influentual zones leads to continuous shoot-outs, and an elevated number of murders[96]. Control of the drug market in the Northern Naples zone and province (Mugnano, Casavatore, Scampia and Secondigliano city districts) is in force with the opposition between the "Di Lauro" clan and the "Scissionisti" clan (divisioners). The conflict is named "Scampia feud".

In the central area of the city, the feuds prevail inside the "Misso" clan in the "Sanità" district. The "Misso" clan is linked to the "Sarno" and "Mazzarella" clans, with some
"Scissionisti" and their boss, Salvatore Torino. In the Vesuvian zone, there is conflict inside of the "Moccia" clan; while in Southern Zone (Torre del Greco and Torre Annunziata) there is the feud between the "Gallo" and "Gionta" clans[97]. This division of territory denotes the remarkable level of conflicts among different criminal associations, more and more jagged and pulverized. The conflicts are likely linked to the will of the majority. The conflict builds and affects the decision-making and control of illegal activities, which remunerate. The vacancy of power that leads to violence just to make sure of (establish) supremacy on the territory. This instability involves the need of the Camorra to lengthen its tentacles and take on interest in extra local economic aspects by exploiting the capital resources and entering in national and foreign financial circuits[98].

The purpose of the Camorra is not just to create a functional societal system. The scope of this system is direct control of the fraud and business activities, through the interactions with professionals able to estimate the market dynamics and direct the activities of criminal associations in the flourishing sectors.

The local criminals have been invaded by a foreign presence. The activities of these foreign groups are conditioned by Camorra approval. For example, Albanians, Nigerians, and Romanians are dedicated to prostitution exploitation and the drug trade, collaborating with Campania's clans. Other foreign groups, like the Chinese and Ukrainians, run the black works, where individuals work in illegal conditions. They also evade the laws about conditions, place, and time of work, exposing their clandestine fellow-countrymen to exhausting shifts just to keep down the market costs. The tendency of Camorra to pursue the financial circuit to be more and more profitable has permitted the Camorra to leave their urban roots, by projecting it in the national and international context[99]. Because of this, it has "permitted" the presence of Campania criminal individuals in other Italian regions, such as Lazio, Toscana, Lombardia, Veneto, Trentino Alto Adige, and Friuli Venezia Giulia, in relation to activities linked to the drugs trafficking, extortion, usurer activities, and money laundering[100].

It is also important to emphasize the emergence of operative bonds in order to run individual deals among Camorra clans with representatives of Sicilian and Calabria clans. These bonds are a connection to international relations to control foreign markets through gangster token roots in foreign States such as Spain, Belgium, Holland, Romania, and Latin America. According to sales, the Neapolitan Camorristi businessmen are involved in different types of criminal market and urban violence. This is the most important feature of Camorra. Although, this prompted the internationalization of the Camorra phenomenon, the organized crimes appear to have strongly local traits, or "napolicentrico". The Camorra is a local-global crime group. It is national and international, but always central to a city 
district[101].

This is the last phase of "Camorra's" evolution. Over time, it has passed through structural transformations which are related both to changes in the social and economical assets and to the globalization of the markets, as well as the links that the local gangs have created with other illegal associations from foreign countries. The black market and the illegal import/export of goods, starting from the 1950's up to the early 1980 's, led to the complicated structure of the Camorra. It followed a verticalized scheme with different operational and responsibility levels. Today we find a new and different organization of Camorra. After the defeat of the most important gangs during the 1980's (due, above all, to the penance phenomena), it is not interested anymore in the territory itself, which is left to the low-level gangs. Interestingly, organizations which deal at an international level are not interested in a liaison with the territory. Nowadays, the Camorra prefer high-level deals, which bring more money (like the international drug traffic), without changing their strategy of maintaining a link with the legal economy and public institutions[102]. In the past, we assisted with these phenomena in the U.S., especially in New York, where the criminal organization composed by Vito Genovese, Frank Costello and Lucky Luciano, was passed into Vincent Gigante's hands. He started to lose control of the territory, and consequentially, also the direction of the organization itself. So, he decided to bound the new generation of mobsters to the finance world and toward the big import-export deals (both legal and illegal). This change, or evolution, can be felt, nowadays, also in the Campania's mob, which is jeopardizing economic safety through the increasing level of infiltration, both in private and financial legal activities[103]. The end of the territory control by big organizations left room for the small gangs to flourish.

Camorra's money is recycled and cleaned in different ways[104]. Police know that the ways utilized most to recycle money is to buy commercial activities, especially medium sized supermarkets, but also to buy the winning tickets of a gambling pool by betting on football results or "superenalotto" as well as and all lotteries and prize competitions. This means that the mobsters who invest in commercial activities are not interested in the amount of money gained, but in the possibility of showing that the money invested is "clean" and comes from legal activities. In the last few years, it has been found that the clans were not only limited to simply "commercialize" because they passed from the simple investment, to real productive activities. For example, two clothes brands for kids called "Favola" and "Emporio junior" were used to hide some clans from "Scampia" and "Secondigliano" which used these brands to recycle money coming from their illegal activities. In Italy, Camorra invest in villas, hotels and other shops. Camorra does not, at least in Italy, hide its riches [105].

On the contrary, the Camorra prefer to show off in order to demonstrate the power reached by the clan. They make it easy for the police investigators to discover the clan's properties. But, today, money coming from illegal activities are often cleaned, recycled and reinvested abroad. In the past only western countries received (most often in Spain), money from Campania's mob. Today Slovakia, Hungary and Romania are the countries where most of the investments are made by clans, which have already made several investments in Germany and in the U.K. In East European countries, investments are extremely different: they involve the property sector, tourism and hotels business sector, which appear to be one of the main ways to recycle money in the commercial sector and in other productive sectors, especially with clothing. Investments abroad started with the "Casalesis"[106]. But not all the Camorra clans have different activities abroad. For instance, the "Nuvolettas", connected with Sicily's "Cosa Nostra" in Campania, invest mainly in northern Italy as well as abroad[107].

The highest level of the organization recycles money with the "puntate" which are business created by free traders of drug trafficing. The income is reinvested with the buying of apartments and hotels, logistic societies, private schools, and even art galleries. This is all capital, which belongs to somebody else. This clan reinvests its income mainly in estates and buildings in Italy even in Emilia Romagna, Veneto, Marche and Lazio regions, where the "Enea Cooperativa di produzione e lavoro" society was used to obtain public clearances in those regions (where they could also recycle dirty money). Abroad, "Nuvolettas" invested mainly in Spain because they had contacts with the local mob and local administrators and have been able to infiltrate in Tenerife's economy and later settle in South America. But, the first to invest abroad have been was the Casalesis, who started their business in Spain, the south France on the "Blue Cost", and, in South America. They have been followed by "Nuvolettas" in these recycle activities. "Casalesis" are those who, together with "Fabbrocino's" clan and "Cesarano's" clan, were more powerful among Campania's mob. It is a shameless and powerful clan able to commit massacres and spill blood without care for anything but leaving a mark. For instance, in the "Simeone's" family massacre, seven people were killed in fourteen days. One of the more cruel examples is the "Di Matteo's" family, where eight people were killed in two different raids separated by one single hour. This clan has liaisons with politicians and the international mob[108]. It has been in relations over the 2006 years with the Antimafia National Office, which is confederation of all the Caserta's clans, and the only camorrist force comparable with "Cosa Nostra" for business capability, economic and military power. The "Schiavone's" family alone, led by Francesco "Sandokan" Schiavone, appears to be able to earn 5 billion euros a year[109].

But the whole clan, led by Antonio Iovine and Michele Zagaria, can achieve even more economic power when taking account of their houses, legal business, and clean activities, which amount to around 30 billion euros a year. Obviously, great traffic makes for great business. Different clans have also increased their activities; first, the building trade, then the garbage business, and lastly, the big business 
of drugs. The presence of "Casalesis" in central and northern Italy is strong. They manage most of the building trade business, bringing with them mostly casertanos workers. This is made possible because certificates and antimafia controls in those areas are less strict, allowing the transfer of entire factory branches or firms. Only after amassing a big fortune can the recycle process begin in the form of houses, tourist villages, firms, societies, and finance. But, "Casalesis" also invested in the productive sector. Likewise, it has been discovered that these clans invested in sugar factories (like the "Ipam"). Further, hundreds of farms and cheese factories in Campania and in Abruzzo, firms which trade in all Italy like the "Italburro" of Carinaro nearby Caserta, were infiltrated. However, analysis can only give an incomplete idea of how big the phenomena of recycling money and of the investments can be. Another clan linked to the "Casalesi's" confederation is the "La Torre's" clan from Mondragone (near Caserta) [110]. After the penance of Augusto, the boss, the criminal agreement has been led by his brother, Antonio La Torre.

It is estimated that this clan earns a huge amount of money via illegal business including extortion, control of economic activities, and contracts in this territory. All the money is reinvested abroad especially in the U.K., where almost all individuals at the top of the organizations live. But the activities carried out by this clan abroad are all perfectly legal, through the use of a the company called "Aberdeen Leasing". This company buys and manages houses and commercial activities, including the restaurant "Pavarotti's", which is even depicted in tour guides online. These groups cannot miss with their illegal activities. Among these activities include drug trafficking and counterfeit money trafficking. Even the clan, known as "Alleanza di Secondigliano" which connected all the clans that were established north of Naples, gave itself a business structure with international connections[111].

They have appearred to be one of the most powerful clans in Europe. It has infiltrated the textile enterprise in central Italy as well. It is so well infiltrated that there is no need to force entrepreneurs to pay "pizzo" because industrialists from north Italy are completely integrated in this camorrist organization.

"Alleanza di Secondigliano" has an economic empire made up by more than 200 million euros. Its activities range from productive activities in areas surrounding Napoli, (such as clothing production in which fake trademarks are printed and sold abroad), to the import of drills from China. Jeans named "Vip Moda", made in a factory of the famous Ciro Bernardi, are sold in Texas as real "Valentino's". Clothing export is also directed toward Spain, Canada, Australia, the U.K., Germany and France. According to the police, this clan is able to create a monopoly in trading some products in many parts of the world. The income from these goods comes back to Italy by passing through bank accounts of figureheads. It is then reinvested in legal activities[112].

Further, the famous clan of Paolo Di Lauro known as
"Ciruzzo 'o milionario", boss of "Secondigliano", considered starting a feud after he got rich through international drug traffic and started to invest abroad. "Ciruzzo" paid a lot of attention to the Asian markets, and he has been able to defeat the competition by investing in camera factories in China. Products are market and exported in many countries, especially in Eastern Europe[113].

It is possible to affirm that in Campania in the last twenty-five years, Camorra played a main role in the economy and society. The economic and social development of this region ceased, and the mob influence and its power increased rapidly. Today, Camorra is in the center of society; economics and politics play just a marginal and secondary role[114]. According to Francesco Barbagallo, Camorra moves 100 billion Euros a year and controls whole markets. It behaves in a very fine way using professional intermediaries and firms, which give up, totally or in part, to pressures made by criminal groups behind them. Camorra has become in these years, an economical and social power which controls politics and society overall because it provides jobs at all professional levels: from the low level employees to the most important professionals.

It is incorrect to affirm, according to Barbagallo, that Camorra is an historical-anthropological kind of phenomena with the same characteristics of the past. Organized mobs in Campania today have gained international importance. They move in markets all around the world and this development increased during the new historical phase of globalization that has been well used in legal enterprises. Camorra infiltrates the economy by using classic methods used by common entrepreneurs but with the advantage of having a great availability of money coming from illegal traffic[115]. Barbagallo says that after the fight against organized mob during early 1990's, a strong withdrawal occurred in the fight against Camorra. This happened because local administrations and police, who are supposed to fight the mob, got literally surrounded, and also because in Campania this phenomena has been minimized in order to avoid the damage to south Italy which would have occurred by talking too much about criminality.

In actuality, the truth is the opposite because if nobody talks, everybody becomes morally guilty. There are several signs which, according to this professor, are a loud warning. The first is the lack of resources available to fight the Camorra. According to Barbagallo, even if the State works hard, and the Camorra becomes a real social and economical power, the fight is unfair.

Recently the Mafias has been becoming real holdings. In order to defeat them, it's necessary to attack their properties and fortune. It is also important not only to confiscate Camorra estates belonging to it but also to be able to manage them. These properties are not normal, but they are characterized by the great symbolic value coming from being associated with the Camorra's property. The villas, large farms, hotels, restaurants, tourist villages, and factories represent much more than simple properties, and more than 
simple tools to make money for the clans. They often become like a symbol to show power and success (becoming the proof of a winning path of economical and criminal actions). Further, when the property is confiscated, if nobody uses it, (due to bureaucracy or intimidation), this represents a confirmation that the clan still has power over the property itself. The problem concerning impounded properties must be analyzed by two different points of view. First, it concerns investigation levels and contract laws. Second, it concerns the interception of recycle flows.

Actually, it has to be said that several properties have been impounded by Camorra's clans and most of them have been reconverted to social uses by local administrations. This also happened with the laws adopted by the Campania region. Two examples include the case of Regional Law 12 in June 13th, 2003 titled "Laws concerning administrative regional and local police and safety policies" as well as Regional Law 11 in December 9th, 2004 which concerned "solidarity measures for criminality victims". Another case involved Regional Law 23 in December 12th, 2003, which ruled that the "Actions for local administrations at which Camorra's confiscated properties have been transferred, according with article 3 of law 109/96".

In particular, Regional Law 23/03 ruled the actions to reinvest properties confiscated for institutional, social and public interest reasons and law 109 of 7 March 1996, created a Foundation to finance projects presented by local administrations to which confiscated properties have been transferred. During the first fiscal year (2004), about 700.000 euros were invested; and, during the second fiscal year (2005), the amount was around 630.000 euros. At the end of 2005, 544 properties were confiscated in Campania, and for all of them it has been found a new destination applying law 109/96 known as Law named "Rognoni-La Torre".

Included in the large number of properties taken (or confiscated) by illegal organizations were 242 apartments, 37 car boxes and garages, 55 buildings, 38 clubs, 163 estates, 9 factories and 168 firms. These properties represent $19 \%$ of the properties confiscated in Italy. These buildings, as well as firms, especially those that were in the territory under a criminal group control, were confiscated to demonstrate the military, economical and social power of the clan itself. For this reason, using these properties for a social aim is the best way to destroy the spectacular power of the bosses. But, it has to be said that for the other 461 buildings impounded in Campania, a destination has not yet been decided.

Statistics show that $57 \%$ of the properties taken from the clans are still free, and formally, they are only available for the State. However, to use a confiscated property, it takes from five to ten years. There are several proposals to create an Authority dedicated to manage the transition of properties from Camorra to local administrations. An authority should also aim to bring in the impounded firms from a close destination in order to gain fiscal support with guaranties for workers. This, of course, occurs only when there is the possibility of quality or legitimate firms themselves; if conditions are to improve, a quality firm level must be used.
Buildings are often a target for vandals belonging to the clan as soon as the confiscation occurs[116]. It gets hard for local administrations and for associations that get these properties to manage and reinvest them due to the heavy economical effort that they have to put forth. It should be noted that the constitution of several farmers' cooperatives like "Agrorinasce", which includes 5 local administrations around Caserta (including Casapesenna, Casal di Principe, San Cipriano d'Aversa, S. Maria la Fossa and Villa Literno) as well as "SOLE, Development, Employment, Economic Loyalty - Cammini di Libertà", which includes some local administrations around Naples, are in place to better manage the transformation of properties confiscated.

Camorra is changing. We can understand it by examining how it uses its means. In the past, often some people decided to become a member of one of Camorra's groups to receive a salary (the "mesata"), but now the situation is different. The salaries are only for intimate members of the clan. For this reason, the unskilled laborers (workers) alternate among the Camorra groups in order to find a better salary. This is a possible motive or incentive to explain some of the micro-crimes in Naples city[117].

Recently, the clans have been reorganizing. Actually, they reorganize continually. This reorganization is due to the fact that the clans do not need more detailed control in the zones. The Camorra do not fear the increased surveillance by policemen. This point can be demonstrated by the many murders in quarters with great police control[118]. However, it is important to repeat that in this period, the clan's affairs are handled out of Naples city. For example, the Nuvoletta family affairs are handled in Spain, the Di Lauro family in China, and the Secondigliano's clan in the U.S.A. These international "jobs" have reduced the need for continuous and strong control in Naples on behalf of the clans[119].

The clans have relied on this typical structure for 80 years. Today, they utilize flexible structures that can be adapted to their requirements. Now, there is an out and out "affair's committee". The existence of this committee has been confirmed by the confessions of very important super groups of clans, including Salvatore Giuliano. He revealed to the judges that three families (the Misso, Mazzarella, and the Di Lauro) had a hegemony in Naples. These families divide up the influenced city districts, the market to occupy, the investments in particular sectors, the extortion's zones, and the contracts etc[120].

So, in contrast to the N.F., that has a common route, and the N.C.O., that created a confederate society, these families have developed a unity similar to the N.C.O. The flexibility of new clans permit them to move the capital quickly, and to invest in property or commercial activities nimbly, without the weight of a territory's choice or political intermediation. The strict structure of the N.C.O. is not a good choice for clans, according to the economical and financial point of view because it has led to the micro-crimes gangs committing crimes in order to find money for their members. Their activities include theft, robbery and aggravated assaults, which are committed by men who want only to 
increase their revenues. The union of these men could be more effective and efficient in their criminal purposes, and they could become interlocutors of important Camorra clans.

We suppose that this is a real reason of the special ferocious actions and effectiveness. These gangs, through their criminal activity and their income, can create real organizations that, even if they cannot be merged into criminal groups, can become the entrepreneurial and criminal organizations at the service of the Camorra clans. This development of Camorra, linked to the changes of old clans in the modern organizations and to spreading of criminals groups engaged in small offenses, has led to more complexity in the criminals phenomena, especially in the bond between them and the micro criminality.

\section{Discussion}

The historical and sociological study about the Camorra has featured in this organization's ability to evolve over a long process of transformation. The Camorra has rooted not only in crime field but also inside the relationships with society and Neapolitan, Campania and national politics. Sometimes, there has been the perception that the Camorra hasn't existed, hidden among the masses, in its cultural and social roots, as a form of spread illegality, finally to re-emerge through discontinuous and irregular relationships with property owners, politics and institutions, with a mercenary goal.

The Camorra has never respected the politics, indifference to its ideologies but not the single politicians as some of them have provided privileges to the clans of the Camorra, in exchange for votes or support.

The Camorra mercenary tradition has centred its efforts on the sectors that have made the Camorra reach endless economical advantages.

The Camorra has never cut its social roots in which it has founded a real phenomenon of mass governing the disorder.

Nowadays, despite of the changes in the economical and social conditions of the classes that traditionally represent it, the Camorra keeps on surviving through a form of modernity that supports it, a kind of living together that gives the Camorra strength and support.

The urban feature makes the Camorra different from the other criminal organizations. It has an horizontal organization in which the fragmentation prevails: a group of gangs, sometimes fighting each other in order to obtain the power the territory. The present organizational asset is flexible and dynamic: it locates the Camorra outside the urban circuit, in a regional, national and international context in search of a more and more convenient financial circuits.

The process of the Camorra modernization hasn't eliminated the sense of belonging that used to and is able to convey to its affiliates. The sense of identity is valued through rituals and oaths that get more and more remarkable inner strength of the neophytes. They are aware of having to respect rigid and strict rules in the same way of the State rules, and the threat of hard sanctions for unfulfillment: everything for society's sake. The Camorra represents a complex phenomenon that has been transformed through social changes to present it as a carrier of positive values, alternatively to the constitutional State, in certain historical moments. It is anti-State, as sometimes Cutolo affirmed in the past. The sociologist Sales[121] has defined the Camorra as a Carsick phenomenon, that has deep roots in the Neapolitan society and comes out intermittently with new features, in relation and connected to the weakness of the State.

The Camorra is the result of the total deligitimacy of institutional powers inside the city and performs complex functions of protection, control and delegation. It is important to call attention to an important distinction: the concept of complex crime organization is different from the one regarding the criminal conspiracy or simple crime organization. The first one is characterized by a strong cultural tie, whereas the second one doesn't present a deep-rooted social and cultural structure, has an only aim, that is to commit crimes. This crime system is characterized by a structured set of actions and illegal behavior that connect the members to the crime environment, institutions and men belonging to the legal system, in order to play an important role in the social, political, administrative and economical life of a large number of modern countries.

The Camorra can be defined as a juridical, economical, anthropological, social and political phenomenon: it is a complex and multiform reality that belongs to a dynamic system of life. These remarks induce the literature to define the Camorra as an extra-State institution, that has an autonomous juridical system in which a strong, authoritarian, strict discipline reigns, in fact the main aspect of this discipline is secrecy[122].

The existence of a strong discipline, characterized by the threat of laws, the law and executive authority, the availability of Tribunals that settle controversies and punish, affiliates inflicting punishment, locate the Camorra in an analogue position of the State, but it is illegal and in opposition to the State[123].

According to the Parliament Commission of Antimafia, the Camorra models exercise an attractive strength on young people. In the opinion of these the Camorra is the only subject that can give an identity and a shadow of integration[124].

As a result this aspect has been conveyed to the present multicultural society, in fact it is registered a new phenomenon regarding the recruitment of a large number of foreign young people that have provided suitable conditions for international illegal interests.

The transnational connation of the organized crime has widened the influence of the illegal activities on larger and larger territories, through connections that don't create problems of overlapping but change the structure of the Camorra, that spread from the origin country. 


\section{Conclusion}

Today the Camorra is not as strong as it was in the Nineties. This does not mean the Camorra is less dangerous. It is a crime business that makes the plan of real development difficult to do or achieve.

Several decades of the Camorra-business have favored the passage from a predatory and parasitic phase to a symbiotic system that is a real integration in the legal system, through the involvement of the white-collar workers.

It is trying to look for possible interventions of prevention and contrast of the Camorra phenomenon, even if Campania is heavily struck by the organized crime in a large number of its areas. The repression action of magistrates and police have been effective and appreciable, thanks to a large numbers of laws, such as the Rognoni-La Torre Law, the law regarding the collaborators of the justice and finally the other one about the heavy prison for mafia crimes.

In Campania the magistrates have been able to bring to light collusion and corruption inside the magistracy. As regard the public armed forces, they have operated with effectiveness and using the most sophisticated techniques of inquires.

The globalization and electronic e-commerce have opened other horizons of the mafia model, giving it to new spaces of actions. Next to the new Empire, as a new worldwide government of economy, an internationalization of organized crime has been taking form with a deep pollution of mankind.

Among the reaction of public opinion there is a group that would like a sort of militarization of the territory. It is highly desirable a perfection in the way the available forces and means are used. If it is fundamental the control of the territory by the armed forces, it is necessary that the local authorities take part in the process of control, developing an effective activity of repression against the unauthorized building, quality control of the urban environment, supporting action in favor of young people who risk to deviance, urban police.

There is no doubt that the Camorra must be fought through an adequate politics of development and international actions. For example: the public administration Reform, the definition of differentiated funds for the South. The Censis has studied the transparency of the public administration and the spread of the culture of legality: the situation hasn't improved yet over these years. The delays and the ineffectiveness of the public apparatus are presented more and more accentuated in the Southern Italy. As result there are serious consequences on the economy and vitality of the business.

The increase of the illegal opportunities is characterized by the present passage of the criminal underworld to the Camorra as a business, that has offered prospective of easy and quick earnings to young people. It is not superfluous add that the juvenile crime is connected to the fact that Naples is the European city presenting the higher rates of compulsory education's evasion. The Neapolitan young live in the illegal economy in which they perform a precious function. He is educated to take part in the Camorra. The market of illegality and crime is increasing because the deviance is the rule in some urban contexts, in which it is possible to learn techniques to commit a crime. In these contexts the illegal and crime activities are not submitted to sanctions, they are valued.

These remarks induce to face the wider and complex problem of responsibility of intellectuals and culture with reference to prevention and fight against the organized crime and sub-cultural background.

There is much evidence of more and more increasing commitment against the illegality. Even the local press is not always coherent and specialized in commenting the news about the phenomenon of common and organized crime. The local daily press gives information to the people about the Camorra in superficial ways, waking emotional reactions, without inducing a serious reflection. The problem doesn't only affect culture or the intellectuals from Southern Italy. It is a national problem that asks for a strong effort in the fight against the Camorra in order to spread and root an organic culture of legality.

\section{REFERENCES}

[1] V. Paliottti. Storia della Camorra, Newton Compton Editori, Roma, 2006.

[2] A. Grado. Dal Crimine Organizzato alla Riorganizzazione del crimine, Edizioni Universitarie Romane, Roma, 2006.

[3] E. Mirabella. Mala vita: gergo, camorra e costumi degli affiliati: con 4500 voci della lingua furbesca in ordine alfabetico. (Prefazione di Cesare Lombroso), F. Perella, Napoli, 1910.

[4] V. Paliotti. Storia della Camorra, Newton Compton Editori, Roma, 2006, pag. 21-22.

[5] V. Paliotti. Storia della Camorra, Newton Compton Editori, Roma, 2006.

[6] A. Grado. Dal Crimine Organizzato alla Riorganizzazione del crimine, Edizioni Universitarie Romane, Roma, 2006.

[7] V. Paliotti. Storia della Camorra, Newton Compton Editori, Roma, 2006.

[8] The "sfregio" is a permanent sign made on face or body of enemies or opponents.

[9] The "sego" is fat of equine, ovine but above all bovine.

[10] Between 1618 and 1621 an "Hermano mayor" became a secretary of the Spanish king Filippo III.

[11] 1 - Ogni galantuomo, fornito di buon occhio, di buone orecchie, buone gambe e punto lingua, può divenire membro della Guarduna. Potranno divenirlo pure le persone rispettabili di una certa età che desidereranno servire la confraternita, sia tenendola al giorno delle buone operazioni da farsi, sia dando i mezzi di eseguire le dette operazioni. 2 La confraternita riceverà eziandio sotto la sua protezione ogni 
matrona che avrà sofferto per la giustizia, e che vorrà incaricarsi della conservazione della vendita dei diversi oggetti che la divina provvidenza si degnerà mandare alla confraternita, nonché le donne giovani che saranno presentate da qualche fratello. Queste ultime a condizione di favorire con tutta la loro anima e con tutto il loro corpo gli interessi della confraternita. 3 - I membri della confraternita saranno divisi in chivatos, postulantes, guapos e fecelles. Le matrone saranno chiamate coberteras e le giovani sirenas. Queste ultime debbono essere giovani, svelte, fedeli e attraenti. 4 - I chivatos, fintantoché non avranno imparato a lavorare, no potranno intraprendere nulla da se soli, e non si serviranno del pugnale che in propria difesa. Saranno nutriti, alloggiati e mantenuti a spese della confraternita. Ciascuno di essi riceverà a questo uopo, dai capi, 136 maravedis al giorno. Nei casi di qualche distinto servigio reso da un chivato, questi passerà subito all'onorevole categoria di postulante. 5 - I postulantes vivranno dei loro artigli; questi fratelli saranno esclusivamente incaricati delle eclissi (furti) operate a mano lesta per conto e per favore dell'ordine. Per ciascuna eclisse il fratello operante riceverà il terzo lordo, dal quale trarrà qualche cosa per le anime del purgatorio. Degli altri due terzi, uno sarà versato alla cassa per le spese di giustizia (per pagare le guardie, $i$ cancellieri e anche i giudici che proteggeranno $i$ fratelli) e per fare dire delle messe per i nostri fratelli trapassati; l'altro per essere messo a disposizione del gran maestro dell'ordine obbligato a vivere alla corte per vegliare al benessere e alla prosperità di tutti. 6 - I guapos avranno per essi gli oscuramenti (accoltellamenti), i sotterramenti (assassini), i viaggi (rapine), i bagni o i battesimi (annegamenti). Di queste due ultime operazioni potranno incaricare un fratello postulante, sotto la loro responsabilità. I guapos avranno il terzo lordo di tutte le operazioni ; soltanto daranno il trenta per cento del loro provento per l'alimentazione e il mantenimento dei chivatos, e quello che vorranno per le anime del purgatorio; il rimanente del prodotto delle loro operazioni sarà distribuito come nell'articolo 5. 7 - Le coberteras riceveranno il dieci per cento su tutte le operazioni che realizzeranno, e le sirenas sei maravedis per ciascuna peseta versata nella cassa della confraternita dai guapos.Tutti i regali che riceveranno dai nobili signori, dai monaci e da altri membri del clero apparterranno loro in proprio. 8 - Il capataz o il capoprovincia sarà nominato fra $\mathrm{i}$ guapos che avranno almeno sei anni $\mathrm{di}$ servizio e che saranno benemeriti della confraternita. 9 - Tutti i fratelli debbono piuttosto morire martiri (torturati) che confessori (delatori), sotto pena di essere degradati, esclusi dalla confraternita, e dal bisogno perseguitati da essa.

[12] Other fraternities came into existence throughout Italy. Masonry was imported from England and France. The Carboneria had been present in South Italy since 1807.

[13] Rule 21 of "Frieno".

[14] M. Marmo. Ordine e disordine: la camorra napoletana dell'Ottocento,Viella, Meridiana, vol. 7-8, 119-155, 1990.

[15] Of clear Spanish origin, extortion to the prisoners not pertaining to the "Bella Società Riformata", the whose cue drew from a picture of a "Madonna" (Our Lady), thought sacred one for the Camorristi was one since deduction sending of the homicides that they committed.

[16] There is one tribunal per quarter.

[17] The sources tell of one raid of the police that succeeded in invading one session in February of 1822, rescuing a certain Giovanni Esposito, who was about to be found guilty by the
Gran Mamma of murdering a district capo while in a fit of rage. In a court was found the follow written: "Room of Justice. The law is equal for all because the Mothers judge not with the pen, like in the courts of the King, but with the heart and the mind".

[18] It was a duel that only consisted in facing itself in group (dichiarimenti) or between two persons (zumpata), with the so-called "molletta" (jack-knife), with the exception of the duels in the Spanish societies that happened with the guns.

[19] So-called "Confraternita of the Guarduna", a Spanish sect that was born in 1417 , specialized in organizing crimes on behalf of thirds party and in perceiving tangents on every risen of activity. It operated until 1822, year in which was rout.

[20] He was the "Contaiuolo" Francesco Scorticelli.

[21] 1 - La Società dell'Umiltà o Bella Società Riformata ha per scopo di riunire tutti quei compagni che hanno cuore, allo scopo di potersi, in circostanze speciali, aiutare sia moralmente che materialmente. 2 - La Società si divide in Maggiore e Minore: alla prima appartengono i compagni camorristi ed alla seconda i compagni picciotti e giovanotti onorati. 3 - La Società ha la sua sede principale in Napoli, ma può avere delle categorie anche in altri paesi. 4 -Tanto $\mathrm{i}$ compagni di Napoli che di fuori Napoli, tanto quelli che stanno alle isole o sottochiave (in carcere) o all'aria libera, debbono riconoscere un solo capo, che è il superiore di tutti $\mathrm{e}$ si chiama capintesta, che sarà scelto fra i camorristi più ardimentosi. 5 -La riunione di più compagno picciotti o di giovanotti onorati si chiama "chiorma" e dipende anche dal capo-società dei compagni camorristi. 6 - La riunione di più compagni camorristi costituisce "la paranza" ed ha per superiore un capintrito o un caposocietà. 7 - Ciascun quartiere deve avere un caposocietà o capintrino, che sarà per votazione scelto fra i camorristi del quartiere e resta in carica un anno. 8 - Se fra le "paranze" vi fosse qualcuno di penna, dietro il parere del capintesta e dopo un sacro giuramento sarà nominato contaiuolo. 9 - Se fra le "chiorme" vi fosse qualcuno di penna, dal picciotto anziano del quartiere sarà presentato al capintrino, dal quale dipende e dietro sacro giuramento, sarà nominato contaiuolo dei compagni picciotti; ma se non si trovasse, il contaiuolo delle paranze farà da segretario anche alle chiorme. 10 - I componenti delle paranze e delle chiorme, oltre Dio, i Santi e i loro capi non riconoscono altre autorità. 11 - Chiunque svela cose della società, sarà severamente punito dalla "Mamme". 12 - Tanto $i$ compagni vecchi che quelli che si trovano nelle isole o sottochiave (in carcere) debbono essere soccorsi. 13 - Le madri, le mogli, le figlie e le innamorate dei camorristi, dei picciotti e dei giovanotti onorati debbono essere rispettate sia dai soci che dagli estranei. 14 - Se, per disgrazia, qualche superiore trovasi alle isole, deve, dagli altri dipendenti, essere servito. 15 - Quattro camorristi sotto chiave possono fra loro scegliersi un capo, che cesserà di essere tale appena toccherà l'aria libera. 16 - Un socio della Società Maggiore, per essere punito, dovrà essere sottoposto al giudizio della Gran Mamma. Un socio della Società Minore sarà condannato dalla Piccola Mamma. Alla Gran Mamma presiede il capintesta e alla Piccola Mamma il capintrito o caposocietà del quartiere di chi deve essere condannato. 17 - Se uno delle chiorme offendesse qualche componente delle paranze, il paranzuolo si potrà togliere la soddisfazione da sé. Avverandosi l'opposto, dovrà essere informato prima il capintesta. 18 - Il dichiarimento si farà sempre dietro parere del capintrito, se trattasi di picciotto o di giovanotto onorato, e dietro il parere del capintesta, se di camorrista. Ai vecchi e agli scornacchiati (i cornuti) sarà vietato di zompare. 19 - Per essere camorrista 
o ci si arriva per novizio o per colpo. 20 - Chi fu implicato in qualche furto $\mathrm{o}$ viene riconosciuto come ricchione (omosessuale passivo) non può essere mai capo. 21 - Il capintesta si dovrà scegliere sempre fra le paranze di Porta Capuana. 22 - Tutte le punizioni delle Mamme si debbono eseguire nel termine che stabilisce il superiore e dietro il tocco (sorteggio). 23 - Tutti i camorristi e i picciotti diventano, a turno, camorristi e picciotti di giornata. 24 - Quelli che sono comandati ad eseguire le tangenti le debbono consegnare per intero ai superiori. Delle tangenti spetta un quarto al capintesta e il resto verrà versato nella cassa sociale a scopo di dividerlo scrupolosamente fra i compagni, fra gli infermi e fra quelli che stanno in punizione per sfizio del governo. 25 - I pali, nella divisione del barattolo, debbono essere trattati ugualmente come gli altri della società. $26-\mathrm{Al}$ presente frieno, secondo le circostanze, possono essere aggiunti altri capitoli.

[22] The "pizzo" was an extortion on a revenue of a trades.

[23] The "biscazzieri" were the playhouse's boss.

[24] M. Marmo. Ordine e disordine: la camorra napoletana dell'Ottocento,Viella, Meridiana, vol. 7-8, 119-155, 1990.

[25] Part of the revenues of the activities of the Camorra was assigns to the maintenance of affiliates in jails.

[26] V. Paliotti. Storia della Camorra, Newton Compton Editori, Roma, 2006.

[27] M. Marmo. Economia e politica della camorra napoletana, nel secolo XIX, Edizioni Liguori, Napoli, 1989.

[28] He reigned between 1825 and 1830.

[29] He reigned between 1830 and 1859 and put into effect immense program of reforms and public works.

[30] In the reign of "Due Sicilie" there were sixteen jails.

[31] The articles 15 previewed: Four Camorristi "under key" can between they choose a head, that he will stop of being such as soon as will "touch the free air".

[32] V. Paliotti. Storia della Camorra, Newton Compton Editori, Roma, 2006.

[33] Cfr. Acts of Commissione d'inchiesta per Napoli presieduta dal Senatore Giuseppe Saredo, in V. Paliotti. Storia della Camorra, Newton Compton Editori, Roma, 2006.

[34] It was the rise of Enrico Alfano, called Erricone, that he structured the Society in various way. He hold a position of effective "capintesta", while Luigi Fucci, called 'O Gassusaro, hold a position of honorary "capintesta". The first one could decide of the "camorristi scelti" (chosen racketeers), while the other of the 12 "capintriti".

[35] Modifications to the "Frieno" were brought from the "capintesta" Ciccio Cappuccio.

[36] G. Gribaudi. Donne, Uomini, Famiglie. Napoli nel '900, L'Ancora del Mediterraneo, Napoli, 1999.

[37] I. Sales. La Camorra. Le Camorre, Editori Riuniti, Roma, 1988.

[38] Salvatore Lucania, alias Lucky Luciano, has been an Italian-American criminal affiliated to the Mafia.

[39] Vito Genovese begins the criminal career working with
Lucky Luciano; been involved in several murders, its rise in the world of the Mafia begins when Lucky Luciano is in exile in Italy.

[40] The "blonde" are cigarettes' contraband. Cfr. G. Di Fiore, Potere Camorrista, Alfredo Guida Editore, Napoli, 1993.

[41] G. Marrazzo. Il Camorrista, Tullio Pironti Editore, Napoli, 2005.

[42] V. Paliotti. Storia della Camorra, Newton Compton Editori, Roma, 2006.

[43] Antonio Spavone, after approximately seven years of freedom, returned in jail because he killed an italoamericano for jealousy reasons. Condemned and then acquitted he was victim of an ambush that disfigured his face. Subsequently, after a short parenthesis American he returned in Italy and he came definitively condemned for mafia association in order then to be acquitted.

[44] V. Paliotti. Storia della Camorra, Newton Compton Editori, Roma, 2006.

[45] The homicide was very bloody, than the Maresca after to have unloaded all the loader of its gun, taken also that one of the brother to riddle with shots Totonno 'and Pomigliano.

[46] A. Grado. Dal Crimine Organizzato alla Riorganizzazione del crimine, Edizioni Universitarie Romane, Roma, 2006.

[47] The triunvirato one was based on a entrusted job to Stefano Bontade, Salvatore Riina, Gaetano Badalamenti, than they were found, also with other sicialian, to Naples and outskirtses in obliged stay. Cfr. A. Grado, Dal Crimine Organizzato alla Riorganizzazione del crimine, Edizioni Universitarie Romane, Roma, 2006.

[48] I. Sales. La Camorra. Le Camorre, Editori Riuniti, Roma, 1988.

[49] V. Paliotti. Storia della Camorra, Newton Compton Editori, Roma, 2006.

[50] G. Marrazzo. Il Camorrista, Tullio Pironti Editore, Napoli, 2005.

[51] V. Paliotti. Storia della Camorra, Newton Compton Editori, Roma, 2006.

[52] Poggioreale was and is a famous jail of Naples.

[53] V. Paliotti. Storia della Camorra, Newton Compton Editori, Roma, 2006.

[54] A. Grado. Dal Crimine Organizzato alla Riorganizzazione del crimine, Edizioni Universitarie Romane, Roma, 2006.

[55] A. Grado. Dal Crimine Organizzato alla Riorganizzazione del crimine, Edizioni Universitarie Romane, Roma, 2006, pag. 24.

[56] G. Gribaudi. Donne, Uomini, Famiglie. Napoli nel '900, L'Ancora del Mediterraneo, Napoli, 1999.

[57] Commissione Parlamentare Antimafia, XI legislatura, Relazione sulla camorra (rel. On. Violante), approvata il 21 dicembre 1993, doc. XXIII n. 12, pubblicata in Camorra e politica, Laterza, Roma-Bari, 1994.

[58] G. Marrazzo. Il Camorrista, Tullio Pironti Editore, Napoli, 2005, pag. 75 . 
[59] 'Ndrangheta was and is the Calabria's criminal organization, as the Camorra was and is the Campania's criminal organization.

[60] V. Paliotti. Storia della Camorra, Newton Compton Editori, Roma, 2006.

[61] Rosetta Cutolo named "woman with ice eyes" was a first lady of N.C.O.

[62] G. Marrazzo. Il Camorrista, Tullio Pironti Editore, Napoli, 2005.

[63] A. Grado. Dal Crimine Organizzato alla Riorganizzazione del crimine, Edizioni Universitarie Romane, Roma, 2006.

[64] Commissione Parlamentare Antimafia, XI legislatura, Relazione sulla camorra (rel. On. Violante), approvata il 21 dicembre 1993, doc. XXIII n. 12, pubblicata in Camorra e politica, Laterza, Roma-Bari, 1994.

[65] Beyond to the Campania's alliances, Cutolo had relationships in Puglia, in Calabria with the 'ndrangheta and the Lombardia's groups which have as leaders Renato Vallanzasca e Francis Turatello.

[66] V. Paliotti. Storia della Camorra, Newton Compton Editori, Roma, 2006, pag. 229.

[67] G. Falcone, M. Padovani. Cose di Cosa Nostra, Prologo alla prima edizione, Rizzoli, Milano, 1991, pag. 34.

[68] The sources indicates the following families as participants at ceremony of foundation of N.F.: Alfieri, Galasso of Poggiomarino, Giuliano, Vollaro, Nuvoletta, Mazzarella, Casalesi, Fabbrocino, Baratto, Picuozzi, Mariano.

[69] G. Marrazzo. Il Camorrista, Tullio Pironti Editore, Napoli, 2005.

[70] An political organization, of extreme left, that was active as terrorist group in Italy in the second half of the last century. Cfr. G. Marrazzo. Il Camorrista, Tullio Pironti Editore, Napoli, 2005.

[71] G. Marrazzo, Il Camorrista, Tullio Pironti Editore, Napoli, 2005, pag. 198.

[72] Ciro Cirillo came kidnapped from the "Brigate Rosse" the 27 April 1981 and his men of supply was killed.

[73] Many sources support that the price for liberation of Cirillo was one milliard and half of lire. Cfr. V. Paliotti. Storia della Camorra, Newton Compton Editori, Roma, 2006.

[74] The "Pentitismo" were confessions from terrorists and from the members of the criminal organization. The practice of pentitismo emerged in Italy during the period of major terrorist activity in the 1970s. Members of terrorist groups, who had been arrested, would collaborate with the authorities by providing information in return for a reduced sentence, or for their own ideological reasons. In recent years it was become common practice for members of Mafia organizations to become "pentiti" (supergrass) and special legislation has been passed to provide for their sentencing and personal protection. The "pentito" is a terrorist or criminal who turns police informer.

[75] Commissione Parlamentare Antimafia, XI legislatura, Relazione sulla camorra (rel. On. Violante), approvata il 21 dicembre 1993, doc. XXIII n. 12, pubblicata in Camorra e politica, Laterza, Roma-Bari, 1994.

[76] The clan, a time was active into the area of Saviano and Nola, turns out practically extinct, also because its boss currently collaborates with the justice.

[77] Commissione Parlamentare Antimafia, XI legislatura, Relazione sulla camorra (rel. On. Violante), approvata il 21 dicembre 1993, doc. XXIII n. 12, pubblicata in Camorra e politica, Laterza, Roma-Bari, 1994.

[78] I. Sales, M. Ravveduto. Le strade della violenza. Malviventi e bande di camorra a Napoli, L'Ancora del Mediterraneo, Napoli, 2006

[79] Commissione Parlamentare Antimafia, XI legislatura, Relazione sulla camorra (rel. On. Violante), approvata il 21 dicembre 1993, doc. XXIII n. 12, pubblicata in Camorra e politica, Laterza, Roma-Bari, 1994.

[80] Commissione Parlamentare Antimafia, XI legislatura, Relazione sulla camorra (rel. On. Violante), approvata il 21 dicembre 1993, doc. XXIII n. 12, pubblicata in Camorra e politica, Laterza, Roma-Bari, 1994.

[81] I. Sales, M. Ravveduto. Le strade della violenza. Malviventi e bande di camorra a Napoli, L'Ancora del Mediterraneo, Napoli, 2006.

[82] Taverna del ferro and Pazzigno are two areas of the industrial quarter of S. Giovanni a Teduccio in the east of Naples.

[83] M. Garofalo. I fortini della camorra, Gruppo Ed. L'Espresso, Limes, vol. 2, 165-173, 2005.

[84] M.F. Palestino. Una favola edificante, in M. Braucci, G. Zoppoli (eds.). Napoli comincia a Scampia, L'ancora del Mediterraneo, Napoli, 2005.

[85] P. Peluso. Dai processi di autoesclusione alla nascita delle contee della camorra nelle periferie napoletane, in G. Palermo (eds.). Studi sulla camorra, Edizioni Labrys, Benevento, 2012.

[86] G. Amendola (eda.). Il governo della città sicura. Politiche, esperienze e luoghi comuni, Liguori Ed., Napoli, 2004.

[87] H. Corman, N. Mocan. Carrots, Sticks, and Broken Windows, The Journal of Law and Economics, vol. 48, 235-266, 2005.

[88] V. Paliotti. Storia della Camorra, Newton Compton Editori, Roma, 2006.

[89] I. Sales, M. Ravveduto. Le strade della violenza. Malviventi e bande di camorra a Napoli, L'Ancora del Mediterraneo, Napoli, 2006.

[90] A. Lamberti. La camorra. Evoluzione e struttura della criminalità organizzata in Campania, Boccia Editore, Salerno, 1992.

[91] For example the name of the clan of "Casalesi" derive by the city of Casal di Principe in Caserta's province.

[92] This classification was operated by I. Sales, M. Ravveduto. Le strade della violenza. Malviventi e bande di camorra a Napoli, L'Ancora del Mediterraneo, Napoli, 2006.

[93] G. Gribaudi. Traffici criminali. Camorra, mafie e reti internazionali dell'illegalità, Bollati Boringhieri, Torino, 2009. 
[94] Muschilli is the nick name of youngs people utilized by Camorra for its illegal activities mainly as drug couriers. F. Barbagallo, M. Marmo, M. Calise, Camorra e criminalità organizzata in Campania, Liguori, Napoli, 1988.

[95] E. Ciconte. Storia criminale. La resistibile ascesa di mafia, 'ndrangheta e camorra dall'Ottocento ai giorni nostri, Rubettino Ed., Soveria Mannelli, 2008.

[96] From 2004 to 2006 there were 247 murders in Naples.

[97] F. Barbagallo. Storia della camorra, Laterza, Bari, 2010

[98] G. Gribaudi. Traffici criminali. Camorra, mafie e reti internazionali dell'illegalità, Bollati Boringhieri, Torino, 2009.

[99] A. Grado. Dal Crimine Organizzato alla Riorganizzazione del crimine, Edizioni Universitarie Romane, Roma, 2006.

[100] S. Morabito. Mafia, 'ndrangheta e camorra nelle trame del potere, Gangemi, Roma, 2005.

[101] I. Sales, M. Ravveduto. Le strade della violenza. Malviventi e bande di camorra a Napoli, L'Ancora del Mediterraneo, Napoli, 2006.

[102] G. Gribaudi. Traffici criminali. Camorra, mafie e reti internazionali dell'illegalità, Bollati Boringhieri, Torino, 2009.

[103] M. Marmo. Il coltello e il mercato. La camorra prima e dopo l'unità d'Italia, L'ancora del Mediterraneo, Napoli, 2011.

[104] R. Capacchione. L'oro della camorra, Bur Rizzoli, Milano, 2008.

[105] F. Barbagallo. Storia della camorra, Laterza, Bari, 2010

[106] R. Capacchione. L'oro della camorra, Bur Rizzoli, Milano, 2008.

[107] E. Ciconte. Storia criminale. La resistibile ascesa di mafia, 'ndrangheta e camorra dall'Ottocento ai giorni nostri, Rubettino Ed., Soveria Mannelli, 2008.

[108] F. Barbagallo. Storia della camorra, Laterza, Bari, 2010

[109] DNA - Direzione Nazionale Antimafia, Relazione annuale sulle attività svolte dal Procuratore Nazionale antimafia e dalla Direzione Nazionale antimafia nonché sulle dinamiche e strategie della criminalità organizzata di tipo mafioso, Ministero della Giustizia, Roma, 2007.

[110] R. Capacchione. L'oro della camorra, Bur Rizzoli, Milano, 2008.

[111] M. Marmo. Il coltello e il mercato. La camorra prima e dopo l'unità d'Italia, L'ancora del Mediterraneo, Napoli, 2011.

[112] F. Barbagallo. Storia della camorra, Laterza, Bari, 2010

[113] S. Morabito. Mafia, 'ndrangheta e camorra nelle trame del potere, Gangemi, Roma, 2005.

[114] E. Ciconte. Storia criminale. La resistibile ascesa di mafia, 'ndrangheta e camorra dall'Ottocento ai giorni nostri, Rubettino Ed., Soveria Mannelli, 2008.

[115] F. Barbagallo. Il potere della camorra (1973-1998), Einaudi Ed., Torino, 1999.

[116] R. Capacchione. L'oro della camorra, Bur Rizzoli, Milano, 2008.

[117] M. Marmo. Il coltello e il mercato. La camorra prima e dopo l'unità d'Italia, L'ancora del Mediterraneo, Napoli, 2011.

[118] P. Peluso. Panico e insicurezza. Strategie di polizia e programmi di prevenzione, Edizioni Labrys, Benevento, 2010

[119] A. Grado. Dal Crimine Organizzato alla Riorganizzazione del crimine, Edizioni Universitarie Romane, Roma, 2006.

[120] F. Barbagallo. Storia della camorra, Laterza, Bari, 2010.

[121] I. Sales, La camorra le camorre, Editori Riuniti, Roma, 1993.

[122] M.S. Giannini, Diritto amministrativo, vol. 1, Giuffrè, Napoli, 1993.

[123] A. Grado. Dal Crimine Organizzato alla Riorganizzazione del crimine, Edizioni Universitarie Romane, Roma, 2006.

[124] Commissione Parlamentare Antimafia, XI legislatura, Relazione sulla camorra (rel. On. Violante), approvata il 21 dicembre 1993, doc. XXIII n. 12, pubblicata in Camorra e politica, Laterza, Roma-Bari, 1994. 